\title{
LISTENING STRATEGIES OF STUDENTS AT ENGLISH EDUCATION STUDY PROGRAM OF PATTIMURA UNIVERSITY AMBON; IMPLICATION FOR TEACHING LISTENING
}

\author{
${ }^{1}$ Christian Albert Lewier \\ lewier_73@yahoo.com \\ ${ }^{2}$ Priska Nendissa \\ FKIP Universitas Pattimura - Ambon
}

\begin{abstract}
The present study investigated the implementation of various strategies performed by Indonesian EFL learners. Sixty students of English Education Study Program at Teachers Training and Educational Sciences Faculty of Pattimura University in Ambon were studied on their use of various listening strategies. The result of the study shows that most of these students applied social/affective strategies (76.6\%) and metacognitive strategies $(46.6 \%)$. The use of these strategies were favored by the students as listening strategy preferences due to their effectiveness in facilitating comprehension. The students' perception on various strategies was identified and implication for teaching listening is further discussed in the article.

Keywords: English as a Foreign Language (EFL), Listening comprehension, listening strategy.
\end{abstract}

\section{Introduction}

Listening has an important role upon a language development process. Although to some extent, its importance might less considered by those who thought that this skill may only be picked up along way the journey of learning other English major skill such as speaking, reading and writing. Listening is a unique skill that needs a systematic and regular training especially in context where English is taught as a foreign language. It is the ability to receive and interpret messages in the communication process. Listening is an effort in the part of listener to gain understanding by using the sense of hearing and the ability of thinking to carry out interpretations received from the speaker's verbal message. Sharma (2011) stated that listening is communication procedures needed by the listener to understand, interpret and assess what they hear. This happened mainly through the process of capturing, understanding and remembering.

Lack of English language skill is partially rooted from the lack of listening skill. As listening is a building block to other language skills, poorly administered listening class may lead to deficiency in language mastery or even failure in language learning process. The challenges faced by many EFL learners in the listening process are vary and considerably complex. The challenges might be in the form of vocabulary limitation, structural component of the text, words recognition until the speaker's pronunciation. These seemingly unbearable aural tasks has left many nonstrategic EFL learners with distressful feeling and gradually being demotivated to continue learning English. 


\section{Foreign Language Learners and the Use of Listening Strategies}

Good language learners use various strategies to help them listen and comprehend spoken English. Listening strategies are procedures that provide and recall listening input directly to the comprehension. In listening, the learners need to know the strategies that can help them comprehend the message from the interlocutors while trying at their best to reduce many comprehension barriers. In other words, the ability to use an appropriate listening strategy may promote comprehension and the training on the use of these strategies is pivotal.

In the listening process, students must be trained to use strategies that will enable them to take active role in communication so effective communication can be established. It its broader sense, Oxford (2003) suggests that strategies are relevant process of behavior or thought that students use to improve their own learning. While listening strategies in particular, can be classified as how the listeners process the input. The listeners must know the background of the topic, the situation, the context as well as kind of text or speech. It can help students interpret what they are listening of, and can anticipate what they will hear next. This implies that for the foreign language learners, listening and listening strategies must be systematically taught and practiced on regular bases.

Canpolat, et al (2015) points out that students used different strategies in some aspect such as cognitive, affective, and psychomotor-based strategies to perform active listening. Generally, some students used cognitive strategies such as paying attention on interlocutors' verbal deliverance, taking notes, making associations and analogies, asking questions and seeking the main ideas. In addition, students also used psychomotor-based strategies such as, being close to the board while activating both the head and the eyes, making eye contact, generating feedback, sitting up straight, paying attention to gestures, facial expressions, tone of voice, and stresses in speech.

\section{Listening and Listening Comprehension defined}

According to Rost (2009 as cited in Ahmadi 2016), listening is an active mental ability that helps us to understand the message delivered in communication. While Sabouri (2016) asserts that listening is a process of receiving what the speaker says, making and showing meaning, negotiating meaning with the speaker and answering, and creating meaning by participation, creativity, and empathy. Additionally, Brown (2001) maintains that listening is the main element in teaching and learning language because in the classroom learners do more listening than speaking. It means that listening is an important process in our daily life within which fully language ability may developed.

In confirming this fact Yildirim (2016) asserts that listening has an important role both in daily life and in academic contexts as it is crucial for people to sustain effective communication. In emphasizing the importance of listening, Anderson and Lynch (2003 in Yildirim 2016) state that listening skills is as important as speaking skill because people cannot communicate face-to-face unless both types of skills are developed together. Additionally, listening skills are 
also important for learning purposes since students receive information and gain insights through listening (Wallace, Stariha \& Walberg, 2004 in Yildirim 2016).

Interestingly, this stipulation is strengthened in general work field by the study of Tyagi (2013) who claims that good listening makes workers become more productive. If message given by the manager responded accordingly because of the good listening and accurate interpretation in the part of the workers, the communication is said to be effective thus leads to optimal required action. Workers can perform the job efficiently upon hearing, understanding, remembering, evaluating and responding the messages. The ability to listen carefully will allow a person to:

a. Understand assignments in better way and find what is expected from him.

b. Build rapport with co-workers, bosses, and clients.

c. Show support.

d. Work better in a team-based environment.

e. Answer questions.

f. Find underlying meanings in what other people say.

Listening ability must be understood as more than just communication. The ability in listening is to go from knowing and doing as evidenced by feedback and response appropriate with the message delivered by the speaker. The listening process is an important factor in the communication process which is influenced by many things. According to Tyagi (2013), listening strategy is the activities or procedures that provide recall and listening input directly to the comprehension. Listening strategy is meaningful as a careful plan for activities to achieve specific listening goals. Listening strategy can also be interpreted as an effort to be anticipated so that the objectives of listening can be achieved.

One element in the listening strategy is mastering various listening approaches. For examples the use of video segment method including news programs, documentary films, dramatic and comedy material. In this method, we can select the portion length of the video segment based on the skill level of our students. First watch the segment without any sound and discuss it together. Encourage the student to identify what they think will be the content of the segment. Then, watch the segment again, this time with the sound, allowing students to take notes as necessary for their skill level. After the segment student can write a brief summary of the segment.

\section{Listening Strategies in Debilitating Comprehension Problems}

Zhang (2012) points out that the importance of strategy is to help learners become more aware of the strategies they could use to learn more effectively, and to monitor and evaluate their listening process. The strategies will lead learners to a better comprehension. In that way student can improve their listening ability. It is evident that students frequently face many obstacles in listening. Particularly for EFL learners, understanding the meaning of each word or sentence can be a great challenge for them. They hardly can understand what the speaker says, due to many unfamiliar words, stressed words or accent that they found strange in their local ears. 
Several difficulties which are experienced by foreign language learners have been identified by linguists and language researchers. Yavuz (2015) for example, has noted some of them. Firstly, people can communicate face to face unless the two types of skills, listening and speaking, are developed in tandem. Secondly, comprehending what people are listening in English as one of the worldwide languages and the fact that there are millions of people who learn and speak using English as their first language, constitute the problem why EFL learners hardly can understand what they are listening. The learners may have developed other skills to some degree but English teachers recognize that listening is the major skill in enabling the learners to use their other skills. Thirdly, people cannot practice listening in the same way as they can practice speaking. At least the part of speaking that has to do with pronunciation because the listener cannot predict the communication (Anderson \& Lynch, 1988 in Yavuz et al, 2015).

EFL educators and teachers in both English as a second or foreign language contexts have tried to suggest methods, teaching approaches, in order to help the learners alleviating cumbersome tasks of attempting to comprehend foreign language speech. Bingol (2014) proposed some strategies by which can help students in improving their listening comprehension skill. Among those strategies, the main ones are listed as cognitive, metacognitive and socio-affective strategies in listening comprehension. The author further provide explanation on each strategy as follow;

1. Cognitive strategy

This is a strategy that is used to understand linguistic input and obtain the data. Learners sometimes do not know the meaning of the words and they try to guess the meaning from the context. This is an example of cognitive strategy. The cognitive strategy is connected to comprehending and accumulating input in short term memory or long-term memory for later access. Comprehension starts with the received data that is analyzed as successive levels of organization-sounds and words as a process of decoding. It is a problem-solving strategy that learners use to deal with the learning task and to ease the acquisition of knowledge. The examples of cognitive strategies include repeating to memorize, summarizing and piecing together details (Bingol, 2014). Similarly, Sabouri et al, (2016) expressed that, there are two types of cognitive strategies in listening: First, bottom-up strategies which covers word-for-word translation, arranging the rate of speech, repeating the oral text, and concentrating on the characteristics of the text. Bottom up strategies are text based on the listener relying on the language in the message, that is, the combination of sounds, words, and grammar that creates meaning. Bottom up strategies include: listening for specific details, recognizing cognates, and recognizing word-order patterns. Listeners need to learn how to use both processes to their advantage depending on their purpose for listening. Bottom-up processing starts with the lower-level decoding of the language system evoked by an external source like incoming aural information, and then moves for interpreting the representation through a working memory of this decoding in relation to higher level knowledge of the context and 
the world. The second one is top-down strategies that involve forecasting, guessing, explaining, and visualization. Top-down processing explains that listening comprehension is achieved through processing which involves prediction and inference on the basis of the hierarchies of facts, propositions, and expectations by using an internal source such as prior knowledge.

2. Metacognitive Strategy

In this strategy, learners are conscious when listening to the text attentively. This strategy deals with learning how to plan, monitor and asses the gathered information from the listening part. This is particularly conducted as pre listening activities (Holden, 2004 in Bingol 2014). Metacognition can be defined as "thinking about one's own thinking" like students who can recognize suitable learning methods in the proper situation. A student may understand he has difficulties in finding the connection between important concepts within a story. If he is taught to use a graphic organizer, such as a concept map to identify the main concepts and connect them together using lines, similar to a spider web, then that student has used metacognition to complete the task (Nelson \& Conner, 2008 in Bingol 2014). Wenden (1998, in Bingol 2014) claims that students who use metacognitive strategies have the following advantages:

1. Learners use learning strategies.

2. They learn faster and integrate the knowledge remarkably.

3. Learners define themselves as constant receivers and can properly deal with all situations.

4. They have self-confident to get help from partners, teachers, or family when needed.

5. They observe and evaluate why they are prosperous learners.

6. They handle the situation when things go wrong throughout the task.

7. Their strategy is compatible with the learning task and adaptation are made to reflect changing conditions.

The metacognitive strategy is also a kind of self-regulated learning. It included the check, monitor, select, revise, and evaluate, etc. For example, for metacognitive planning strategies, learners would clarify the objectives of an anticipated listening task, and attend to specific aspects of language input or situational details that assisted in understanding the task. Generally, it can be discussed through pre-listening planning strategies, while-listening monitoring strategies, and post-listening evaluation strategies.

3. Socio-affective strategy

According to Sabouri et al (2016) socio-affective strategies are techniques that listeners use to cooperate with others, to check their comprehension, and to reduce their apprehension. Affective strategies are very significant because the learning situation and learners' social-psychological factors are closely related to each other. There is significant relationship between low anxiety and high listening performance that is, the use of affective strategies makes easy and improve listening. Among all four strategies of 
listening comprehension, social and affective strategies had the most effect on the learning context. Socio-affective strategies are related to students' interaction with other speakers and their reactions towards learning. In socio-affective strategy, students should know how to decrease anxiety, feel confident during listening activities, and raise motivation in improving listening skill.

As mentioned earlier, the three strategy areas in listening, namely cognitive, metacognitive and socio-cognitive help students in the EL learning process, the process of thinking, solving problems and making decisions. Cognitive strategies reflect how one learns, remembers, and thinks and how to motivate themselves. Metacognitive strategy is the ability to learn how learning should be carried out which includes the planning, monitoring and evaluation processes. Socio-affective strategy is the strategies that can help students to improve their listening skill, because these strategies related to interacting with other students, the speakers and students' ability towards learning in listening activity.

\section{Methodology}

In accordance with deLeeuw (2008), this study collected quantitative information which was systematically gathered from a relatively large sample taken from population (p. 2). Students' strategies in listening activities in English Education study program were investigated through the following procedure.

\section{Population and Sample}

In conducting the research, a battery of questionnaire was distributed to students at English Education Study Pprogram in Advanced listening class at Faculty of Teacher Training and Educational Science of Pattimura University. The subject of this study was the students enrolled in Advanced Listening class in academic year 2015/2016. These students were chosen as population of this study that conform to specific criteria and to whom the researchers intended to generalize the result of the research (McMillan, 1996 in Fauzi, 2012). This study took a sample which is made up of individuals, items or events selected from a larger group referred to as a population (Gay, et al 2006 as cited in Fauzi, 2012). In addition, Arikunto (2006) defined sample as some or representative of the population for examination. In carrying out the survey according to Arikunto, if the subject is less than 100 the researcher is recommended to take all the population to become the sample. If the number of the subject is larger, then the researcher should take $10-15 \%$ or $20-25 \%$ or more. Since the number of population was 60 , then the researchers took all students as the sample.

\section{Technique of collecting the data}

This present study used a battery of questionnaires that contains questions items concerning the purpose of the research.

\section{Questionnaire}

The instrument used to gain data from the respondents is questionnaire which has undergone validation process. Creswell (2008) stated that the 
questionnaire is a form used in a survey design that participant in a study complete and return to the researcher.

\section{Result and Discussion}

\section{Quantitative Data}

To answer research questions of this study, two questions were addressed to be answered by 60 English Education Study Program students. The answers of the questions can be categorized into two areas; 1) the strategy that commonly used by the students, 2) the students' perception towards strategy in listening.

\section{The strategy that the students mostly used in listening activity}

To find out the strategies that commonly used by the students in listening, three area of strategies were listed and the students have ticked the kind of strategy they heavily used, frequently used, sometimes used, rarely used and never used in listening. The following table shows the result of their responds:

Table 1. Strategies commonly used by students in listening.

\begin{tabular}{|c|c|c|c|c|c|}
\hline \multirow[t]{2}{*}{ Type of Strategies } & NU & RU & $\mathbf{S}$ & FU & HU \\
\hline & $\mathrm{F}(\%)$ & F (\%) & $\mathrm{F}(\%)$ & $\mathbf{F}(\%)$ & F (\%) \\
\hline $\begin{array}{cl}\text { Metacognitive strategies } \\
\text { - } & \text { Pre-listening } \\
& \text { strategies } \\
\text { - } & \text { While-listening } \\
& \text { monitoring } \\
& \text { strategies } \\
\text { - } & \text { Post-listening } \\
& \text { evaluation } \\
& \text { strategies }\end{array}$ & $2(3,3)$ & $4(6,6)$ & $19(31,6)$ & $28(46,6)$ & $7(11,6)$ \\
\hline $\begin{array}{ll}\text { Cognitive strategies } \\
\text { - } & \text { Cognitive formal } \\
& \text { practicing } \\
& \text { strategies } \\
\text { - } & \text { Bottom-up } \\
& \text { strategies } \\
\text { - } & \text { Top-down } \\
& \text { strategies }\end{array}$ & - & $2(3,3)$ & $25(41,6)$ & $25(41,6)$ & $8(13,3)$ \\
\hline $\begin{array}{l}\text { Social/Affective } \\
\text { strategies } \\
\text { - Social Strategies } \\
\text { - } \quad \text { Affective } \\
\\
\text { Strategies }\end{array}$ & - & $3(5)$ & $11(18,3)$ & $30(50)$ & $\begin{array}{l}16 \\
(26,6)\end{array}$ \\
\hline
\end{tabular}

$N U=$ Not used, $R U=$ Rarely Used, $S U=$ Sometimes used, $F U=$ Frequently used, $H U=$ Heavily Used

From the result above, it can be seen that, $11,6 \%$ of the respondents were heavily used Metacognitive strategies, 46,6\% respondents frequently used it, 31,6 respondents used it sometimes, $6,6 \%$ chose rarely used and 3,3\% respondents not used metacognitive strategies. Meanwhile, for cognitive strategies $11,6 \%$ respondents chose heavily used, $46,6 \%$ frequently used, $41,6 \%$ respondents chose 
to used sometimes, and 3,3\% rarely used. Besides, 26,6\% respondents were heavily used social/affective strategies, 50\% chose Frequently used, 18,3\% respondents preferred sometimes used, and 5\% respondent were rarely used any of the strategy. From the findings above, it can be concluded that the strategies that commonly used by the students in listening are: metacognitive strategies and social/affective strategies. Most of the respondents chose from heavily to frequently use of these strategies.

\section{The students' perception on strategy used in listening.}

In finding out the students' perception towards strategy in listening, 10 statements were provided in metacognitive strategies. The following table presents the result of the research.

Table 2. Students' perception on strategy used in listening.

\begin{tabular}{|c|c|c|c|c|c|}
\hline \multirow[t]{2}{*}{ Statements } & \multicolumn{5}{|c|}{ Degree of Frequency } \\
\hline & SD & $\mathbf{D}$ & $\mathbf{U}$ & $\mathbf{A}$ & $\mathbf{S A}$ \\
\hline $\begin{array}{l}\text { Before listening, I anticipate the listening } \\
\text { task and use strategies to more understand }\end{array}$ & - & $2(3,3)$ & $11(18,3)$ & $38(63,3)$ & $9(15)$ \\
\hline $\begin{array}{l}\text { Before listening, I prepare my Mind to } \\
\text { concentrate. }\end{array}$ & - & $2(3,3)$ & $3(5)$ & $24(40)$ & $31(51,6)$ \\
\hline $\begin{array}{l}\text { Before listening, I always commit myself t } \\
\text { make progress }\end{array}$ & - & - & $9(15)$ & $32(53,3)$ & $19(31,6)$ \\
\hline $\begin{array}{l}\text { While listening, I don't understand if I am } \\
\text { unfamiliar with the speakers' accents. }\end{array}$ & $1(1,6)$ & $3(5)$ & $21(35)$ & $21(35)$ & $14(23,3)$ \\
\hline $\begin{array}{l}\text { While listening, I will check what Part of } \\
\text { content I don't understand. }\end{array}$ & - & $4(6,6)$ & $4(6,6)$ & $31(51,6)$ & $21(35)$ \\
\hline $\begin{array}{l}\text { While listening, I will double check again } \\
\text { my answer }\end{array}$ & - & $3(5)$ & $10(16,6)$ & $21(35)$ & $26(43,3)$ \\
\hline $\begin{array}{l}\text { I am aware of my inattention and correct it } \\
\text { while doing listening test. }\end{array}$ & - & $3(5)$ & $15(25)$ & $25(41,6)$ & $17(28,3)$ \\
\hline $\begin{array}{l}\text { After listening, I reflect on my problems, } \\
\text { such as the key words that I don't understa }\end{array}$ & - & $3(5)$ & $6(10)$ & $17(28,3)$ & $34(56,6)$ \\
\hline $\begin{array}{l}\text { After listening, I evaluate how much I cou } \\
\text { understand }\end{array}$ & - & $1(1,6)$ & $6(10)$ & $24(40)$ & $30(50)$ \\
\hline $\begin{array}{l}\text { I will write down the words I don't know } \\
\text { after the listening tests and look up the } \\
\text { dictionary }\end{array}$ & $2(3,3)$ & $3(5)$ & $4(6,6)$ & $25(41,6)$ & $26(43,3)$ \\
\hline
\end{tabular}

$(n=60)$

As can be seen in the table above, for the first statement, some respondents $(15 \%)$ of the respondents stated strongly agree that, before listening, they anticipate the listening task and use strategies to better understand it. Meanwhile, 
most respondents $(63,3 \%)$ stated agree, several of them $(18,3 \%)$ stated uncertain, and a few of them $(3,3 \%)$ stated disagree. In second statements, $51,6 \%$ of the respondent who were strongly agree that, before listening, they prepare their mind to concentrate, $40 \%$ respondent agree, $5 \%$ were uncertain and 3,3\% were disagree. For the third statements, 31, a small amount $6 \%$ of the respondents stated strongly agree that before listening, they always commit themself to make progress, while about $53,3 \%$ of the respondents stated agree, and $15 \%$ of the respondents stated uncertain.

In line with the fourth statement which is while listening, they don't understand if they were unfamiliar with speakers' accents, $23,3 \%$ of the respondents were strongly agree, $35 \%$ agree, $35 \%$ uncertain, $5 \%$ disagree and $1,6 \%$ were disagree. Dealing with the fifth statement, $35 \%$ of the respondents were strongly agree that, while listening, they will check what part of content they don't understand. There were $51,6 \%$ of the respondent who agree but slightly 6, 6\% stated uncertain and 6,6\% also disagree. In regards to the sixth statements, $43,3 \%$ of the respondents stated strongly agree that, while listening, they will double check again for their answer. Meanwhile, 35\% of the respondents agreed, $16 \%$ of the respondents were uncertain, and $5 \%$ stated disagree.

For the seventh statement, there were $28,3 \%$ of the respondents stated agree that, they were aware of their inattention and correct it while doing listening test. Meanwhile, $41,6 \%$ of the respondents stated agree, $25 \%$ of the respondents stated uncertain and 5\% said disagree. In line with the eight statement, 56, 6\% of the respondents stated strongly agree that, after listening, they reflect on their problems, such as the key words that they don't understand. Next, 28, 3\% of the respondent agreed, $10 \%$ were uncertain and 5\% stated strongly disagree. Furthermore, for the ninth statements, $50 \%$ of the respondents stated strongly agree that, after listening, they evaluate how much they could understand. While $40 \%$ of the respondents agreed, $10 \%$ were uncertain, and small $1,6 \%$ of the respondents said disagree.

Referring to the tenth statement, $43,3 \%$ of the respondents stated strongly agree that, they will write down the words they don't know after the listening tests and look up the dictionary, $41,6 \%$ stated agree, $6,6 \%$ gave uncertain answer, 5\% stated disagree and only 3,3\% who were strongly disagree. From the result above it can be confirm that, strategy has an important role for the English study program students at Pattimura University since from the data shown in table that most respondents were strongly agree and agree. Furthermore, there also listening strategy such as Cognitive Strategies that consist of Cognitive Formal Practicing Strategies, Bottom-up Strategies, and Top-down Strategies. The result is shown in the table below.

Table 3. Students' perception towards strategy in listening (2)

\begin{tabular}{|l|c|c|c|c|c|}
\hline \multicolumn{1}{|c|}{ Statements } & \multicolumn{5}{c|}{ Degree of Frequency } \\
\cline { 2 - 6 } & SD & D & U & A & SA \\
\hline $\begin{array}{l}\text { I practice English listening } \\
\text { actively in daily lives, such as } \\
\text { listening to English radio } \\
\text { programs, English songs and }\end{array}$ & - & $3(5)$ & $15(25)$ & $23(38,3)$ & $19(31,6)$ \\
\hline
\end{tabular}




\begin{tabular}{|c|c|c|c|c|c|}
\hline talking to foreigners & & & & & \\
\hline $\begin{array}{l}\text { While listening, I try to translate } \\
\text { words or sentences into Indonesian }\end{array}$ & - & $1(1,6)$ & $15(25)$ & $26(43,3)$ & $18(30)$ \\
\hline $\begin{array}{l}\text { While listening, I apply the new } \\
\text { vocabulary, phrases, or grammar I } \\
\text { have learned to understand the } \\
\text { content. }\end{array}$ & - & - & $8(3,3)$ & $32(53,3)$ & $20(33,3)$ \\
\hline $\begin{array}{l}\text { While listening, I will notice the } \\
\text { information questions such as } \\
\text { "who, how, when, where and } \\
\text { what" in the content }\end{array}$ & $1(1,6)$ & $4(6,6)$ & $14(23,3)$ & $29(48,3)$ & $12(20)$ \\
\hline $\begin{array}{l}\text { While listening, I try to understand } \\
\text { each word }\end{array}$ & - & $3(5)$ & $6(10)$ & $29(48,3)$ & $22(36,6)$ \\
\hline $\begin{array}{l}\text { While listening, I repeat words } \\
\text { or phrases softly or mentally }\end{array}$ & - & $3(5)$ & $20(33,3)$ & $21(35)$ & $16(26,6)$ \\
\hline $\begin{array}{l}\text { While listening, I piece things } \\
\text { together from the details }\end{array}$ & - & $3(5)$ & $29(48,3)$ & $22(36,6)$ & $6(10)$ \\
\hline $\begin{array}{l}\text { I listen for main ideas first and } \\
\text { then details }\end{array}$ & - & $2(3,3)$ & $10(16,6)$ & $26(43,3)$ & $22(36,6)$ \\
\hline $\begin{array}{l}\text { I predict or make hypotheses on } \\
\text { texts by titles. }\end{array}$ & - & $6(10)$ & $15(25)$ & $28(46,6)$ & $11(19,3)$ \\
\hline $\begin{array}{l}\text { I can guess the meaning based on } \\
\text { the context. }\end{array}$ & $1(1,6)$ & $2(3,3)$ & $14(23,3)$ & $25(41,6)$ & $18(30)$ \\
\hline $\begin{array}{l}\text { I try to think in English instead of } \\
\text { Indonesian }\end{array}$ & - & $2(3,3)$ & $16(26,6)$ & $27(45)$ & $15(25)$ \\
\hline $\begin{array}{l}\text { While listening, I form pictures } \\
\text { mentally to help me comprehend } \\
\text { texts. }\end{array}$ & $2(3,3)$ & $5(8,3)$ & $16(26,6)$ & $26(43,3)$ & $11(18,3)$ \\
\hline $\begin{array}{l}\text { I collect the contents of listening to } \\
\text { my personal experiences }\end{array}$ & $1(1,6)$ & $8(13,3)$ & $16(26,6)$ & $25(41,6)$ & $10(16,6)$ \\
\hline
\end{tabular}

The table above revealed that for the eleventh statements, 31, 6\% of the respondents stated strongly agree that, they practice English listening actively in daily lives, such as listening to English radio programs, English songs and talking to foreigners. Meanwhile, 38, 3\% agreed, 25\% of the respondents said uncertain, and $5 \%$ said disagree. For the twelfth statements, $30 \%$ of the respondents stated strongly agree that, while listening, they try to translate words or sentences into Indonesian. 43, 4\% stated agree, $25 \%$ choose uncertain, and 1, 6\% stated disagree. For the thirteen statements $33,3 \%$ of the respondents stated strongly agrees that, while listening, they apply the new vocabulary, phrases, or grammar they have learned to understand the content. Meanwhile, 53, 3\% stated agree, and 13, 3\% stated uncertain.

In fourteenth statement, $20 \%$ of the respondents strongly agree that, while listening, they will notice the information questions such as "who, how, when, where and what" in the content. While 48, 3\% agreed, 23, 3 of the respondent were uncertain, $6,6 \%$ disagree and $1,6 \%$ respondent stated strongly disagree. For 
the fifteenth statement, $36,6 \%$ of the respondents strongly agree that, while listening, they try to understand each word, while $48,3 \%$ of the respondents agree, $10 \%$ uncertain and $5 \%$ of the respondents were disagree. Moreover, for the sixteenth statement, 26, $6 \%$ of the respondents strongly agreed that, while listening, they repeat words or phrases softly or mentally. Meanwhile, 35\% respondents were agree, $33,35 \%$ were uncertain and only $5 \%$ disagree.

Next, for the seventeenth statements, $10 \%$ of the respondents were strongly agree that, while listening, they piece things together from the detail, there were $36,6 \%$ of respondents who agree, 48,3 of the respondents stated uncertain, and $5 \%$ of the respondents stated strongly disagree. In regards to the eighteenth statements, $36,6 \%$ of the respondents stated strongly agree that they listen for main ideas first and then detail. Meanwhile, 43, 3\% of the respondents were agree, there were 16, 6\% who uncertain and 3, 3 disagree. For nineteenth statements there were 18,35 of the respondents strongly agree that they predict or make hypotheses on texts by titles. While $46,6 \%$ of the respondents stated agree, $25 \%$ stated uncertain, and $10 \%$ respondents sated disagree.

Meanwhile, for the twentieth statements, $30 \%$ of the respondents strongly agree that they can guess the meaning based on the context, 41,6 of the respondents were agree, 23,3 who uncertain, 3,3\% stated disagree, and 1,6\% who strongly disagree. Dealing with the twenty one statement, $25 \%$ of the respondents were strongly agree that they try to think in English instead of Indonesian, 43\% of the respondents agree, while $26,6 \%$ of the respondents said uncertain and 3,4\% stated disagree. For the twenty two statement $18,3 \%$ of the respondents strongly agree that while listening, they form pictures mentally to help me comprehend texts, $43,3 \%$ of the respondents agree, $26,6 \%$ said uncertain, $8,3 \%$ of the respondents stated disagree and 3,3\% only strongly disagree.

In line with the twenty three statements $16,6 \%$ of the respondents strongly agree that they collect the contents of listening to their personal experiences, next $41,6 \%$ respondents agree, 26,6\% said uncertain, 13,3 of the respondents were disagree and only $1,65 \%$ sated strongly disagree. Therefor from the result above it can be conclude that, strategy has an important role in learning listening for students at English study program. Therefore, another strategy in listening that can be used by the students like social/affective strategies. The result is shown in table below.

Table 4. Students' perception towards strategy in listening (3)

\begin{tabular}{|l|l|l|l|l|l|}
\hline \multirow{2}{*}{ Statements } & \multicolumn{5}{|c|}{ Degree of Frequency } \\
\cline { 2 - 6 } & \multicolumn{1}{|c|}{ SA } & \multicolumn{1}{c|}{ D } & \multicolumn{1}{c|}{ U } & \multicolumn{1}{c|}{ SA } \\
\hline $\begin{array}{l}\text { If I don't understand what } \\
\text { someone says in English, } \\
\text { I ask them to repeat what } \\
\text { they said }\end{array}$ & $1(1,6)$ & $1(1,6)$ & $2(3,3)$ & $\begin{array}{l}33 \\
(55)\end{array}$ & $2338,3)$ \\
\hline $\begin{array}{l}\text { After listening, I ask my } \\
\text { classmates or teacher } \\
\text { questions I don't } \\
\text { understand }\end{array}$ & - & $1(1,6)$ & $\begin{array}{l}13 \\
(21,6)\end{array}$ & $\begin{array}{l}29 \\
(48,3)\end{array}$ & $1728,3)$ \\
\hline $\begin{array}{l}\text { I hope teachers can teach } \\
\text { me more skills to improve } \\
\text { my listening }\end{array}$ & - & - & $6(10)$ & $\begin{array}{l}17 \\
(28,3)\end{array}$ & $37(61,6)$ \\
\hline
\end{tabular}




\begin{tabular}{|l|l|l|l|l|l|}
\hline comprehension. & & & & & \\
\hline $\begin{array}{l}\text { While listening, I can } \\
\text { keep calm and not be } \\
\text { nervous. }\end{array}$ & - & $2(3,3)$ & $12(20)$ & $\begin{array}{l}29 \\
(48,3)\end{array}$ & $17(28,3)$ \\
\hline $\begin{array}{l}\text { I am confident in } \\
\text { understanding the whole } \\
\text { contents. }\end{array}$ & - & $4(6,6)$ & $18(30)$ & $\begin{array}{l}28 \\
(46,6)\end{array}$ & $10(16,6)$ \\
\hline $\begin{array}{l}\text { I encourage myself } \\
\text { through positive-self talk. }\end{array}$ & - & - & $7(11,6)$ & $\begin{array}{l}32 \\
(53,3)\end{array}$ & $21(35)$ \\
\hline
\end{tabular}

For twenty four statements, there were only $38,3 \%$ of the respondents that strongly agree that if they don't understand what someone says in English, they ask them to repeat what they said, $55 \%$ of the respondents stated agree, while $3,3 \%$ said uncertain, $1,6 \%$ of the respondents stated disagree and strongly disagree. Dealing with the twenty five statements $28,3 \%$ of the respondents strongly agree that, after listening, they ask their classmates or teacher questions they don't understand. Meanwhile, 55\% stated agree, 21, $6 \%$ of the respondents who disagree and only 1, 6 said disagree. For the twenty six statements $61,6 \%$ of the respondents strongly agree that they hope teachers can teach me more skills to improve their listening comprehension, 28, 3\% choose agree, and 10\% stated uncertain.

In twenty seventh statements $28,3 \%$ of the respondents strongly agree that While listening, they can keep calm and not be nervous, $48,3 \%$ of the respondents stated agree, while $20 \%$ of the respondents stated uncertain and only 3,3\% said disagree. In regards to the twenty eight statements, $16,6 \%$ of the respondents strongly agree that they confident in understanding the whole contents. Meanwhile, $46,6 \%$ of the respondents were agree, there were $30 \%$ who uncertain and 6, 6\% stated disagree. Lastly, for the twenty nine statements $35 \%$ of the respondents strongly agree that they encourage myself through positive-self talk, 53,3 were agree and $11,6 \%$ stated uncertain.

\section{Discussions}

\section{The strategies that the students commonly used in listening of English study program.}

The result of the survey that most of English students in English study program $(76,6 \%$ of the respondents) used social/affective strategies in listening. They believed that social/affective strategies can improve their learning outcome and encourage themselves through positive-self talk. On the other hand, as explained in previous section where Sabouri et al, (2016) stated that, Socioaffective strategies are techniques that listeners use to cooperate with others, to check their comprehension, and to reduce their apprehension. Affective strategies are very significant because the learning situation and learners' socialpsychological factors are closely related to each other. It means that socioaffective strategies are related to students' interaction with others speakers and their reaction towards learning. 
Lastly, the most used strategies in listening activity is metacognitive strategy. The researcher considers metacognitive that use to check what part of content, reflect problems, such as the key words that that they don't understand. Zheng (2016) stated that metacognitive strategies used to make a plan for learning, think about the occurring learning process and evaluate the learning upon the finish of an activity. It helps students to facilitate their listening process. Thus, from that point of view it can be seen that metacognitive gave a positive support in helping students in the learning process. O'Malley and Chamot (1990 in Whiple et al 2006) this strategy thinking about the learning process, planning for learning, monitoring the learning task and evaluating how one has learned. Therefore, it becomes important thing for the students to be used to carry out receptive or productive language learning task.

\section{The English Students' perception about strategy in listening}

The findings obtained from survey conducted to English students of English study program revealed that most of the students agreed that before listening, they anticipate the listening task and use strategies to more understand it. It becomes a strong foundation to them to prepare their mind to concentrate before listening because some respondents agree that before listening they commit their self to make progress, it useful for them to be more attention in listening process. Furthermore some respondents agree that while listening, they don't understand if they unfamiliar with speakers' accents, because students English study program are EFL students. Due to the respondents agree that it is important for them to check what part of content that they don't understand and some of the respondents also strongly agree that very important for them to double check again about their answer. Because they aware about their inattention and they have to correct it while doing listening test. They believe that after listening, they reflect on their problems, such as the key words that they don't understand, because it is important for them to evaluate how much they understand after listening and write down the words that they don't know and look up the dictionary to know about the word.

Moreover, some of the respondents agree that they practice English in the daily lives such as listening to English radio programs, English songs and talking to foreigners. It brings benefit for them to approve their listening skill. While listening, they also try to translate words or sentences into Indonesian because English is second language for the students at English study program. The data show that the respondents agreed that they apply the new vocabulary, phrases, or grammar they have learned to understand the content. Around 48, 3\% of the respondents agree that they will notice the information questions such as "who, how, when, where and what" in the content, and they try to understand each word, they believe that it becomes the strong foundation for them during listening process. from the result it can be showed that the respondents agree that the listen for main ideas first and then details, predict or make hypotheses on texts by titles, can guess the meaning based on the context, and collect the contents of listening to their personal experiences. 
On the other hand some respondents agree that if they don't understand someone says they ask them to repeat it again, also some respondents agree that they ask their classmate or the teacher questions if they don't understand, they believe that through this way they can build the relationship with the others and hope that teacher can teach them more skill to improve they listening comprehension. Lastly, while listening $48 \%$ respondents agree that they have to keep calm and not to be nervous while listening and some respondents also agree that they confident in understanding the whole contents and they admitted that they encourage them self through positive self-talk.

In conclusion, the English students at English study program at Pattimura University have positive perception toward the strategy in listening. This positive perception leads to the idea that they are aware of how important the strategy used by English students at English study program in listening process such as listening task, exam but also dealing with the communication in real life confidently and wisely.

\section{Conclusion}

The use of strategy in listening is really important. The students can perform their listening activity better and well-structured if they apply strategy in their listening process. Furthermore, the students can also learn how to improve themselves through the use of appropriate strategy in the classroom. Generally, the strategy that commonly used by the students at English Education study program at Pattimura University are Metacognitive Strategies (pre-listening Planning strategies, while-listening Monitoring Strategies, Post listening Evaluation strategies), Cognitive Strategies (cognitive formal practicing strategies, Bottom-up strategies, Top-down strategies), Social/affective Strategies. To sum up, those three strategies are effective in helping the EFL learners in the listening process.

\section{References}

Ahmadi, M. S. 2016. The Importance of Listening Comprehension in Language Learning. University of Guilan, Rasht, Iran

Arikunto, S. 2006. Prosedur Penelitian Suatu Peendekatan Praktik. Jakarta: PT Rineka Cipta.

Bano, F 2017. Towards Understanding Listening Comprehension in EFL Classroom: The Case of the Saudi Learners. King Abdulaziz University. Saudi Arabia.

Bingol, A.M et al 2014. Listening Comprehension Difficulties Encountered By Students In Second Language Learning Class. Ishik University IRAQ.

Brown, H. D. 2001. Teaching By Principles. New York: Practices-Hall Regents. (Page:247). 
Canpolat, M. et al 2015 Active Listening Strategies of Academically Successful University Students. Mustafa Kemal University, Faculty of Education, Department of Primary Education.

Creswell, J. W. 2008. Educational Research (Planning, Conducting, and Evaluating Quantitative and Qualitative Research). University of Nebraska-Lincoln

Fauzi, 2012. Teaching Speaking Using Cooperative learning Strategy At Seventh Class Students of MTS Al-LUTHFAH Cililin. STKIP Siliwangi Bandung.

Leeuw, D. 2008 International Handbook of Survey Methodology. Utrecht University.

Oxford. L. R. 2003 Language learning style and strategies: an overview. University of Maryland, College Park.

Sabouri, B. N \& Gilakjani, P. A. 2016. Learners' Listening Comprehension Difficulties in English Language. Islamic Azad University. Irak

Sharma, N. 2011. Strategies for Developing Listening Skills. Raj Kumar Goel Institute of Technology Ghaziabad (UP), India

Sudjana, N. \& Ibrahim. 2007. Penelitian dan Penilaian Pendidikan. Bandung: Sinar Harapan Algensindo.

Tyagi, B. 2013. Listening : An Important Skill and Its Various Aspect. Dept.of Professional Comm

Yavuz, F. et al 2015. Problems and Activities in Listening Skills in EFL Classrooms; from Tradition to a more Comprehensible Input. Balikesir University, Necatibey Education Faculty. Turkey

Yildrim, S. et al 2016. The Importance of listening In language learning and listening comprehension problem experienced by language learner: a literature review. Üniversitesi Ĕ̈itim Fakültesi Dergisi

Zhang. Y. 2012. The Impact of Listening Strategy on Listening Comprehension. University of Finance and Economics. 